\title{
Changes in white muscle transcriptome induced by dietary energy levels in two lines of rainbow trout (Oncorhynchus mykiss) selected for muscle fat content
}

\author{
Catherine-Ines Kolditz ${ }^{1}$, Elisabeth Plagnes-Juan ${ }^{1}$, Edwige Quillet ${ }^{2}$, Florence Lefèvre ${ }^{3}$ \\ and Françoise Médale ${ }^{1 *}$ \\ ${ }^{1}$ INRA, UMR1067 Nutrition Aquaculture and Genomics, Pôle d'Hydrobiologie, F-64310 Saint-Pée-sur-Nivelle, France \\ ${ }^{2}$ INRA, UMR de Génétique Animale et Biologie Intégrative, Bâtiment 231, F-78350 Jouy-en-Josas, France \\ ${ }^{3}$ INRA, UR1037 SCRIBE, Campus de Beaulieu, F-35042 Rennes Cedex, France
}

(Received 3 April 2009 - Revised 23 July 2009 - Accepted 24 August 2009 - First published online 30 October 2009)

\begin{abstract}
Energy intake and genetic background are major determinants of muscle fat content in most animals, including man. We combined genetic selection and dietary energy supply to study the metabolic pathways involved in genetic and nutritional control of fat deposition in the muscle of rainbow trout (Oncorhynchus mykiss). Two experimental lines of rainbow trout, selected for lean (L) or fat (F) muscle, were fed with diets containing either 10 or $23 \%$ lipids from the first feeding, up to 6 months. At the end of the trial, trout exhibited very different values of muscle fat content (from 4.2 to $10 \cdot 1 \%$ wet weight). Using microarrays made from a rainbow trout multi-tissue cDNA library, we analysed the molecular changes occurring in the muscle of the two lines when fed the low-energy or high-energy diet. The results from microarray analysis revealed that eleven metabolism-related genes were differentially expressed according to the diet while selection resulted in expression change for twenty-six genes. The most striking observation was the increased level of transcripts encoding the VLDL receptor and fatty acid translocase/CD36 following both the high-fat diet and upward selection for muscle fat content, suggesting that these two genes are relevant molecular markers of fat deposition in the white muscle of rainbow trout.
\end{abstract}

Muscle lipid: Genetic selection: Dietary treatment: Fatty acid translocase/CD36: VLDL receptor

Muscle lipid storage provides an important energy source for muscle functions under specific conditions such as prolonged muscular exercise ${ }^{(1,2)}$ or during fasting ${ }^{(3)}$. In the animal farming industry, muscle lipid levels also affect meat quality in terms of its nutritional value and sensory properties ${ }^{(4,5)}$. Dietary manipulation and genetic selection are the two main tools to manage muscle fat levels in farm animals. Genetic factors and energy intake are known to affect muscle fat content in $\operatorname{man}^{(6)}$. However, the molecular mechanisms controlling muscle lipid deposition are not fully understood.

Salmonids have a high ability to store fat in white muscle ${ }^{(7)}$ and are known to exhibit a large range of variations in muscle fat content under dietary manipulation (from $3 \%$ to as much as $18 \%$ fresh matter $)^{(4,8,9)}$, thus making these species particularly suitable for the study of mechanisms involved in muscle fat deposition and mobilisation. Using divergent selection on muscle fat content, we have been able to generate two lines of rainbow trout (Oncorhynchus mykiss) having either a fatty muscle $(\mathrm{F})$ or a lean muscle $(\mathrm{L})^{(10)}$. We combined the use of these two lines with long-term feeding of diets of different energy levels in order to obtain animals having very different levels of muscle fat content (from 4.2 to $10.1 \%$ wet weight) depending on their genetic background and the level of dietary energy.

As in man and birds, endogenous lipids in fish are mainly synthesised in the liver, and then transported to peripheral tissues by the bloodstream ${ }^{(11,12)}$. Muscle lipid content in these species thus results from the metabolic balance among dietary fat supply, de novo fatty acid synthesis in the liver, uptake of plasma TAG by muscle, and subsequent partitioning of fatty acids toward storage or oxidation for meeting the energy requirements. Studying gene expression and activity levels of selected key enzymes of lipid metabolism, glycolysis and energy production provided the first information on the metabolic changes induced in the liver and the white muscle by the selection process and changes in dietary energy ${ }^{(13)}$. The high-energy (HE) diet repressed the activity of the lipogenic enzymes and stimulated those involved in $\beta$-oxidation and glycolysis in the liver but induced minor changes in the muscle enzymes we tested. The change in muscle fat content induced by selection and dietary treatment was not associated with a change in activity and expression of lipoprotein lipase

Abbreviations: ADT, ATP/ADP translocase; CEL, carboxyl ester lipase; F, fat muscle line; FAT/CD36, fatty acid translocase/CD36; HE, high-energy; L, lean muscle line; LE, low-energy; LPL, lipoprotein lipase; SDH, serine dehydratase.

* Corresponding author: Dr Françoise Médale, fax +33 5595451 52, email medale@st-pee.inra.fr 
(LPL) or enzymes involved in fatty acid oxidation in muscle. In order to identify the molecular mechanisms responsible for the difference in muscle fat content induced by the selection process and dietary treatment, we used in the present study an overall approach at the transcriptome level. Our aims were: (1) to assess the overall metabolic changes induced in white muscle of rainbow trout by long-term feeding of a HE/high-fat diet; (2) to identify the metabolic differences induced in muscle as a consequence of the selection procedure; (3) to evaluate whether the two factors (genetic $v$. nutritional) used to modify muscle fat content act through the same metabolic pathways.

\section{Materials and methods}

\section{Experimental animals and diets}

The animals used in the present study were the same as those described in Kolditz et al. ${ }^{(13)}$. The two lines of rainbow trout, designated $\mathrm{L}$ (lean muscle line) and $\mathrm{F}$ (fat muscle line), were obtained after three generations of divergent selection for high or low muscle fat content, evaluated using a non-destructive method (Distell Fish Fatmeter) in live fish. Trout were reared in the INRA's experimental facilities (PEIMA, Sizun, France) at a constant water temperature of $11.5 \pm 0.5^{\circ} \mathrm{C}$. Just before the first feeding time, fish of each line were distributed into six tanks of 500 animals (mean body weight $0 \cdot 16 \mathrm{~g}$ ). Triplicate groups of each genotype were fed to satiation two diets containing either 100 (low-energy (LE) diet) or 230 (HE diet) $\mathrm{g}$ lipid/kg DM from the first feeding for 6 months. The two diets were made from the same fishmeal-based mixture, and about $15 \%$ fish oil was added to the HE diet to create a wide difference in lipid content between the two diets. The increase in dietary crude fat content $(+135 \%)$ was accompanied by a decrease in the proportions of protein $(-11 \%)$ and starch $(-23 \%)$ in the HE diet (Table 1). At the end of the 6-month feeding trial, and $24 \mathrm{~h}$ after the last meal, all fish were anaesthetised with 2-phenoxyethanol at the recommended dose $(0.2 \mathrm{ml} / \mathrm{l})$, and individually measured for weight and length. From each tank ten fish were sampled, pooled, ground and freeze-dried before being analysed for fat content of the whole body. From each tank nineteen fish were killed by a sharp blow on the head. Viscera were weighed in order to calculate the viscero-somatic index (VSI):

$$
\operatorname{VSI}(\%)=100 \times(\text { total viscera weight } / \text { body weight }) .
$$

Fillets from the left side of the fish were kept after trimming and skin withdrawal as samples for analysis of lipid content. Also, three additional fish per tank were sampled for liver

Table 1. Chemical composition of experimental low-energy (LE) and high-energy (HE) diets

\begin{tabular}{lrr}
\hline Diet... & LE & HE \\
\hline DM (\%) & $93 \cdot 0$ & $93 \cdot 3$ \\
Protein (\% DM) & $57 \cdot 6$ & $51 \cdot 1$ \\
Lipid (\% DM) & $9 \cdot 8$ & $23 \cdot 1$ \\
Starch (\% DM) & $12 \cdot 1$ & $9 \cdot 2$ \\
Energy (kJ/g DM) & 21.0 & $23 \cdot 8$ \\
\hline
\end{tabular}

and white muscle under RNAse-free conditions to perform gene expression analysis. All the tissue samples were frozen in liquid $\mathrm{N}_{2}$ and stored at $-80^{\circ} \mathrm{C}$ until analysis. The experiment was conducted following the National Guidelines on Animal Care of the French Ministry of Research and authorisation to experiment (no. 5228) was delivered to the F. M. by the French Ministry of Agriculture and Fisheries.

\section{RNA extraction}

The RNA extracts used for the present microarray and realtime PCR analyses were the same as those described by Kolditz et al. ${ }^{(13)}$ for expression analysis of candidate genes. Total RNA was extracted from eight individual muscles per experimental condition using the TRIzol reagent method (Invitrogen, Carlsbad, CA, USA). Total RNA was quantified using spectrophotometry based on absorbance at $260 \mathrm{~nm}$ and integrity was monitored using the Agilent 2100 Bioanalyser (Agilent Technologies, Kista, Sweden).

\section{cDNA microarray production}

Nylon microarrays were obtained from INRA-GADIE Biological Resources Centre (http://www.crb.jouy.inra.fr; Jouy-en-Josas, France). A total of 9023 rainbow trout cDNA originating from a normalised multi-tissue library ${ }^{(14)}$ were spotted after PCR amplification onto Hybond $\mathrm{N}+$ membranes as previously described ${ }^{(15)}$. Positive (luciferase) and negative (water) controls were also spotted on each microarray. Positive controls allowed checking that hybridisation ran smoothly and negative (water) spots were used for checking the absence of non-specific hybridisation and for calculation of the background level.

\section{Microarray hybridisation and signal processing}

Five muscle RNA samples from each experimental condition were used for microarray hybridisation at the INRA UMR 1067 transcriptome facility (St-Pée-sur-Nivelle, France). Initial hybridisation was performed at $42^{\circ} \mathrm{C}$ for $48 \mathrm{~h}$ using a ${ }^{33}$ P-labelled oligonucleotide sequence (TAATACGACTCACTATAGGG) present at the extremity of each PCR product to monitor the amount of cDNA in each spot. After three washes (three times for $1 \mathrm{~h}$ at $42^{\circ} \mathrm{C}, 0 \cdot 1 \times$ saline sodium citrate (SSC), $0.2 \% \mathrm{SDS}$ ), arrays were exposed for $48 \mathrm{~h}$ to phosphor-imaging plates before scanning using a phosphorimager (Fuji BAS 5000; Fujifilm Corp.; Tokyo, Japan). The oligo probe was then removed from the arrays (three times for $1 \mathrm{~h}$ at $68^{\circ} \mathrm{C}$, $0.1 \times \mathrm{SSC}, 0.2 \% \mathrm{SDS}$ ) and all the membranes were checked for effective stripping of the oligo probe. Arrays were then prehybridised for $1 \mathrm{~h}$ at $65^{\circ} \mathrm{C}$ in hybridisation solution $(5 \times$ Denhardt's solution, $5 \times \mathrm{SSC}, 0.5 \%$ SDS). Labelled cDNA samples were prepared from $3 \mu \mathrm{g}$ of RNA by simultaneous reverse transcription and labelling for $1 \mathrm{~h}$ at $42^{\circ} \mathrm{C}$ in the presence of $1.85 \mathrm{MBq}(50 \mu \mathrm{Ci})\left[\alpha-{ }^{33} \mathrm{P}\right] \mathrm{dCTP}, 5 \mu \mathrm{M}$-cold dCTP, $0.8 \mathrm{~mm}$ each dATP, dTTP, dGTP and 200 units SuperScript $^{\mathrm{TM}}$ III RT (Invitrogen, Carlsbad, CA, USA) in $30 \mu \mathrm{l}$ final volume. RNA was degraded by treatment at $68^{\circ} \mathrm{C}$ for $30 \mathrm{~min}$ with $1 \mu \mathrm{l} 10 \%$ SDS, $1 \mu \mathrm{l} 0.5 \mathrm{M}$-EDTA and $3 \mu \mathrm{l} 3 \mathrm{M}-$ $\mathrm{NaOH}$, and then equilibrated at room temperature for 
15 min. Neutralisation was performed by adding $10 \mu \mathrm{l} 1 \mathrm{M}-2$ amino-2-hydroxymethyl-propane-1, 3-diol- $\mathrm{HCl}$ plus $3 \mu \mathrm{l} 2 \mathrm{M}-$ $\mathrm{HCl}$. Then $2 \mu \mathrm{g}$ PolydA 80 mers were added to the solution to saturate the polyA tails. Arrays were incubated with the corresponding denatured labelled cDNA for $40 \mathrm{~h}$ at $65^{\circ} \mathrm{C}$ in hybridisation solution. After three washes (three times for $1 \mathrm{~h}$ at $68^{\circ} \mathrm{C} ; 0.1 \times \mathrm{SSC}, 0.2 \% \mathrm{SDS}$ ), arrays were exposed for $60 \mathrm{~h}$ to phosphor-imaging plates before scanning using a phosphorimager (Fuji BAS 5000; Fujifilm Corp.).

\section{Microarray signal processing}

Signal intensities were quantified using AGScan software ${ }^{(16)}$, and normalisation was performed using BASE software (BioArray Software Environment), a MIAME-compliant database available at the SIGENAE bioinformatics facility (http:// www.sigenae.org/). Spots with an oligonucleotide signal lower than three times the background level (calculated as the median value of the negative controls for each membrane) were excluded from the analysis. After correction, signal processing was performed using the oligonucleotide vector data to correct each spot signal according to the actual amount of DNA present in each spot. After correction, the signal was normalised by dividing each gene expression value by the median value of the array before log transformation. Microarray data from the present study have been deposited in the GEO database $(\mathrm{GSE} 16577)^{(17)}$.

\section{Statistical analysis of microarray data}

A total of 7688 clones out of 9023 (85\%) passed through the background filter and were kept for further analysis. To evaluate potential interactions of diet and genotype, variations in gene expression were analysed for each gene by two-way ANOVA $(P<0.01)$ using Tiger TMEV 3.1 software $^{(18)}$, with dietary treatment and genotype as independent variables. When differences were significant, means were compared using the Student-Newman-Keuls test.

\section{Data mining}

Rainbow trout sequences originating from INRA AGENAE ${ }^{(19)}$ and $\mathrm{USDA}^{(20)}$ expressed sequence tags sequencing programs were used to generate publicly available contigs (Sigenae: http://www.sigenae.org). The 8th version (Om.8, released January 2006) was used for Blast $\mathrm{X}^{(21)}$ comparison against the Swiss-Prot database (January 2006) (Swiss-Prot: http:// www.expasy.org/sprot/). This was performed automatically for each expressed sequence tag spotted onto the membrane and used to annotate the 9023 clones of the microarray. For all genes identified as differentially expressed in the transcriptome analysis, ontologies were obtained using GoMiner software (http://discover.nci.nih.gov/gominer/) and completed when necessary with information from the literature. When feasible, functional categories were allocated as they relate to muscle biology.

\section{Gene expression analysis: quantitative RT-PCR}

Eight individual samples per experimental condition, including the five samples used for microarray hybridisation, were used as biological replicates. Real-time PCR measurements were performed as described in Kolditz et al. ${ }^{(13)}$. Specific primer pairs were designed using Primer3 software (http:// biotools.umassmed.edu/bioapps/primer3_www.cgi) according to the transcript sequences that were spotted onto the array. The Genbank accession numbers, the sequences of the forward and reverse primers and the corresponding annealing temperature used for each gene tested for its expression are summarised in Table 2. Relative quantification of the target gene transcript with the elongation factor $\mathrm{I} \alpha(e f l \alpha)$ reference gene transcript ${ }^{(22)}$ was performed according to the $\Delta \Delta \mathrm{CT}$ method described by Pfaff( ${ }^{(23)}$. The effects of dietary treatment, line and line-diet interaction on real-time PCR data were tested using SAS ${ }^{\circledR}$ statistical software (SAS Institute, Inc., Cary, NC, USA) by a two-way ANOVA. Differences were considered significant when the probability level was $<0 \cdot 01$. When differences were significant, means were compared using the Student-Newman-Keuls test.

\section{Results}

Growth parameters and body lipid content of fish are reported in Fig. 1. Feeding the HE diet led to an increased whole-body weight and length $\left(P=10^{-4}\right)$ irrespective of the line. As expected, whole-body and muscle lipid content as well as the viscero-somatic index were higher in fish fed the HE diet compared with fish fed the LE diet $\left(P=10^{-4}\right.$ and $P<10^{-4}$, respectively), irrespective of the genetic background. At the end of the 6-month trial, the whole-body weights and lengths of the trout of the lean muscle line (L) were higher $\left(P=10^{-4}\right)$ than those of the fat muscle line $(\mathrm{F})$. Whole-body lipid content was similar for the two lines fed the same diet $(P=0 \cdot 27)$. Muscle lipid content was significantly higher in fish of the $\mathrm{F}$ line $\left(P<10^{-4}\right)$, whereas visceral fat deposition was increased in the $\mathrm{L}$ line $\left(P<10^{-4}\right)$. A line $\times$ diet interaction was observed for muscle fat level $(P=0 \cdot 003)$, with a marked increase in $\mathrm{F}$ fish fed the $\mathrm{HE}$ diet. Muscle fat content thus ranged from $4.2 \%$ wet weight in the L line fed the LE diet to $10 \%$ wet weight in the $\mathrm{F}$ line fed the $\mathrm{HE}$ diet at the end of the feeding trial (mean fish weight 60-90 g). The other two groups (L-HE and F-LE) had similar muscle fat contents (6.4\% wet weight).

\section{Muscle transcripts differentially expressed between the dietary treatments}

Analysis of microarray findings showed that thirty-five genes were differentially expressed between the two dietary treatments $(P<0 \cdot 01)$; fifteen genes were up-regulated and twenty were down-regulated in the white muscle from the HE-fed group, compared with that from the LE-fed group. The categories of biological function represented in this set of genes are summarised in Fig. 2(A). The complete list of genes that were differentially expressed is presented in Table 3. The identity and biological function of four of them are unknown. About one-third (eleven genes) of the differentially expressed genes were related to metabolic processes: seven were involved in protein and amino-acid metabolism, three in lipid metabolism, and one in the antioxidant pathway. In particular, two clones exhibiting significant sequence homology with mammalian transcripts 
encoding the VLDL receptor and the fatty acid translocase (FAT/CD36), both involved in lipid uptake in muscle and adipose tissue, were significantly more abundant in fish fed the HE diet than in those fed the LE diet. The HE diet also increased the expression of the gene encoding lipoic acid synthase, involved in the detoxification of activated oxygen species. Concomitantly, genes encoding proteins involved in the regulation of ubiquitin-dependent proteasomal proteolysis (ubiquitin carboxyl-terminal hydrolase 2, ubiquitin carboxylterminal hydrolase L1, 26S proteasome non-ATPase regulatory subunit 7), amino-acid catabolism (L-serine dehydratase $(\mathrm{SDH})$ ) and peroxisomal fatty acid oxidation (peroxisomal 3, 2-trans-enoyl-CoA isomerase) were under-expressed in the HE-fed group.

\section{Transcripts expressed differentially between the two lines}

The two-way ANOVA $(P<0 \cdot 01)$ showed that eighty-two genes were differentially expressed between the two rainbow trout lines. In the muscle of the $\mathrm{F}$ line sixty genes were expressed at a higher level and twenty-two at a lower level compared with that of the $\mathrm{L}$ line. The list of the genes that were differentially expressed in the muscle of the two lines is presented in Table 4, and Fig. 2(B) summarises the different categories of biological functions represented by this set of genes. The identity and biological function of eleven of them are unknown. The largest number of genes differentially expressed between the two genotypes were those related to metabolic processes (twenty-six genes; $32 \%$ ). Of these, seven were involved in lipid and sterol metabolism, five in energy production, two in the antioxidant pathway, six were related to protein metabolism, four had functions in amino acid metabolism, one in carbohydrate metabolism and one in $\mathrm{Cu}$ metabolism. Transcript levels of ATP/ADP translocase (ADT), cytochrome c oxidase sub unit 3, isocitrate dehydrogenase (NADP dependent) isoform 2, involved in mitochondrial energy production, and cardiolipin synthase, the last enzyme involved in the synthesis of cardiolipin phospholipid, an important component of the inner mitochondrial membrane, were significantly higher in the $\mathrm{F}$ line than in the L line. Transcript levels corresponding to carboxyl ester lipase (CEL) and prosaposin, a precursor of sphingolipid activator proteins required for lysosomal degradation of sphingolipids, were also higher in the $\mathrm{F}$ line than in the $\mathrm{L}$ line.

Transcripts encoding PPAR $\alpha$, microsomal PGE synthase 2 and two transcripts encoding enzymes involved in the antioxidant pathway (ATP-binding cassette transporter 7 and cytochrome P450 2K1) were expressed at lower levels in the $\mathrm{F}$ line than in the $\mathrm{L}$ line.

\section{Transcripts involved in line-diet interactions}

We detected nineteen transcripts for which the effects of the diet were dependent on genotype. The different categories of biological function represented are summarised in Fig. 2(C) and the corresponding list of genes is presented in Table 5 . Of these, four have unknown functions, one encoded a protein involved in the cell cycle, one in vesicle-mediated transport, one cell structure, five encoded transcription factors and two were involved in metabolic pathways. The latter two had 
functions in purine metabolism and encoded $\mathrm{P} 2 \mathrm{X}$ purinoceptor 3 , which was significantly lower in the L-HE group than in the other three groups, as was deoxyuridine $5^{\prime}$-triphosphate nucleotidohydrolase, which was concomitantly increased in the L-HE group. It is worth noting that most of the significant line-diet interactions observed (fourteen out of the nineteen) consisted of increased or decreased transcript levels in the L-HE group. Their biological relevance was difficult to interpret in the light of the phenotype traits recorded, especially regarding how they relate to muscle fat content.

\section{Confirmation of microarray findings with real-time RT-PCR}

We then selected a set of candidates from the gene lists described above and proceeded with a real-time RT-PCR analysis of their transcript levels using eight RNA extracts, including the five used for microarray hybridisation. These genes were those encoding VLDL receptor and FAT/CD36, due to their function in cellular uptake of blood-derived lipids, PPAR $\alpha$, due to its key role in lipid metabolism, CEL, also known as bile-salt activated lipase, ADT, a rate-limiting enzyme of the respiratory chain, and finally SDH, a key enzyme of amino acid catabolism. It is of note that the $\operatorname{PPAR} \alpha$ sequence assayed in the present experiment was not the same as those analysed in the previous study ${ }^{(13)}$.

The diet-induced changes detected in the expression of VLDL receptor, FAT/CD36 and SDH in the microarray analysis were confirmed by real-time RT-PCR analysis. There were higher transcript levels for VLDL receptor and FAT/ CD36 $\left(P=10^{-3}\right.$ and $10^{-4}$, respectively) and concomitant lower transcript levels for $\operatorname{SDH}\left(P<10^{-4}\right)$ in fish fed the HE diet than in fish fed the LE diet (Fig. 3). In addition,

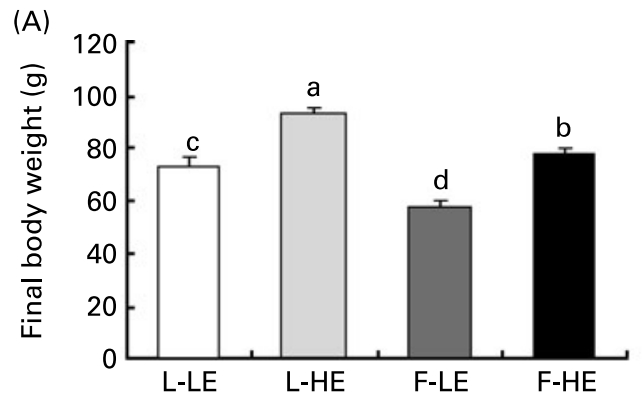

(B)

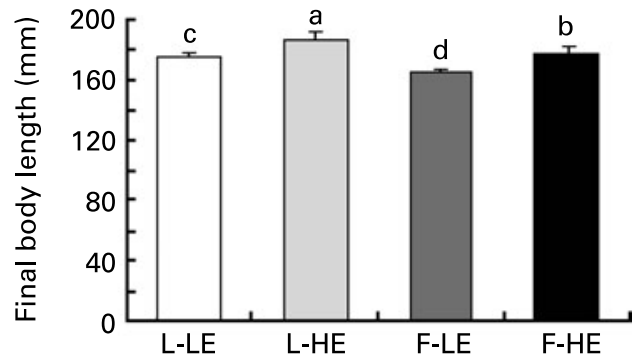

(C)

(D)
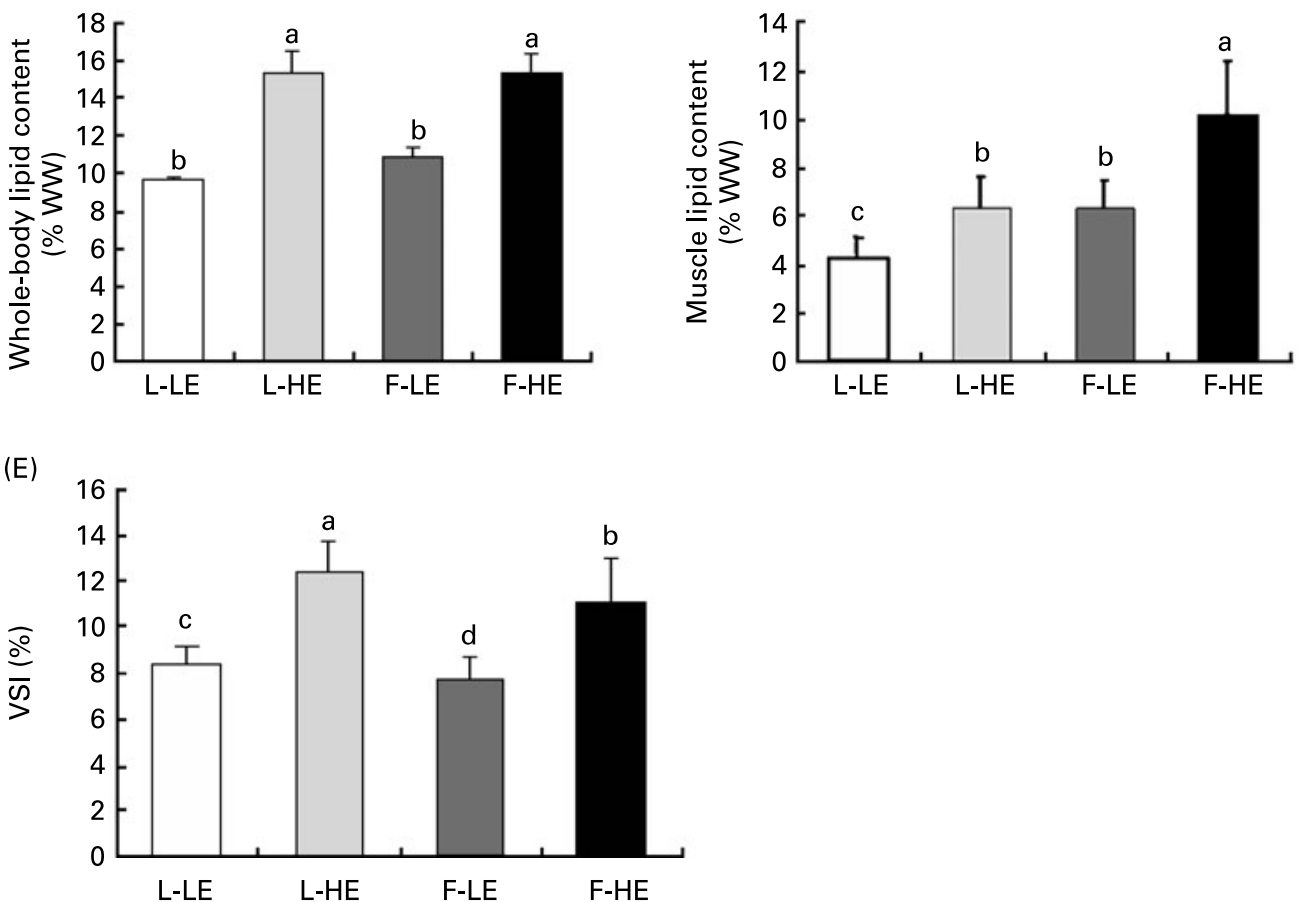

Fig. 1. Body composition of trout (Oncorhynchus mykiss) from the lean muscle line (L) and fat muscle line (F) fed the low-energy (LE) and high-energy (HE) diets for 6 months. Values are means, with standard errors represented by vertical bars ( $n 57$ individuals in all groups, except for muscle lipid content, for which $n 30$ ). (A) Final body weight (g). $\mathrm{HE}>\mathrm{LE}\left(P=10^{-4}\right) ; \mathrm{L}>\mathrm{F}\left(P=10^{-4}\right)$ (two-factor ANOVA). (B) Final body length (mm). $\mathrm{HE}>\mathrm{LE}\left(P=10^{-4}\right) ; \mathrm{L}>\mathrm{F}\left(P=10^{-4}\right)($ two-factor ANOVA). (C) Whole-body lipid content (\% wet weight (\% WW)). HE $>\mathrm{LE}\left(P=10^{-4}\right) ; \mathrm{F}=\mathrm{L}(P=0.27)$ (two-factor ANOVA). (D) Muscle lipid content (\% WW). $\mathrm{HE}>\mathrm{LE}\left(P<10^{-4}\right) ; \mathrm{F}>\mathrm{L}\left(P<10^{-4}\right)$ (two-factor ANOVA). (E) Viscero-somatic index (VSI; \%). HE $>\mathrm{LE}\left(P=10^{-4}\right)$; L $>\mathrm{F}\left(P=10^{-4}\right)($ two-factor ANOVA). $\mathrm{a}, \mathrm{b}, \mathrm{c}, \mathrm{d}$ Mean values with unlike letters were significantly different $(P<0.05$; ANOVA). 
real-time RT-PCR measurement of VLDL receptor and FAT/CD36 transcript levels revealed a significant line effect $\left(P<10^{-2}\right.$ and $<5 \times 10^{-3}$, respectively) with higher expression in the $\mathrm{F}$ line than in the L line (Fig. 3), an effect that was not revealed in the microarray analysis. In real-time
RT-PCR analysis, hybridisation conditions (annealing temperature, primer probe design) were optimised according to the sequence of the target genes, making this technique generally more reliable, sensitive and specific for quantification of mRNA expression than microarray.

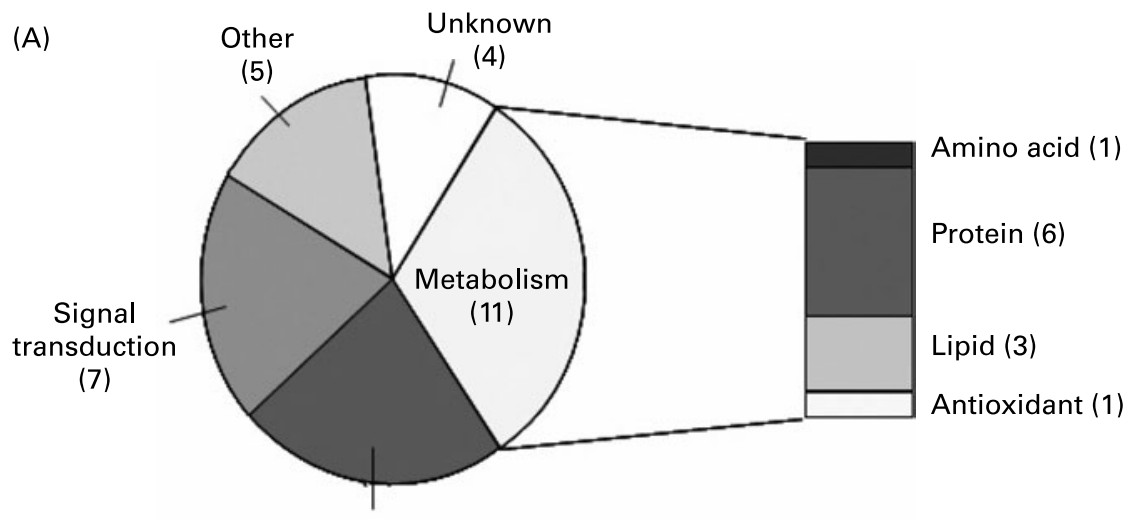

Transcription/translation

(8)

(B)

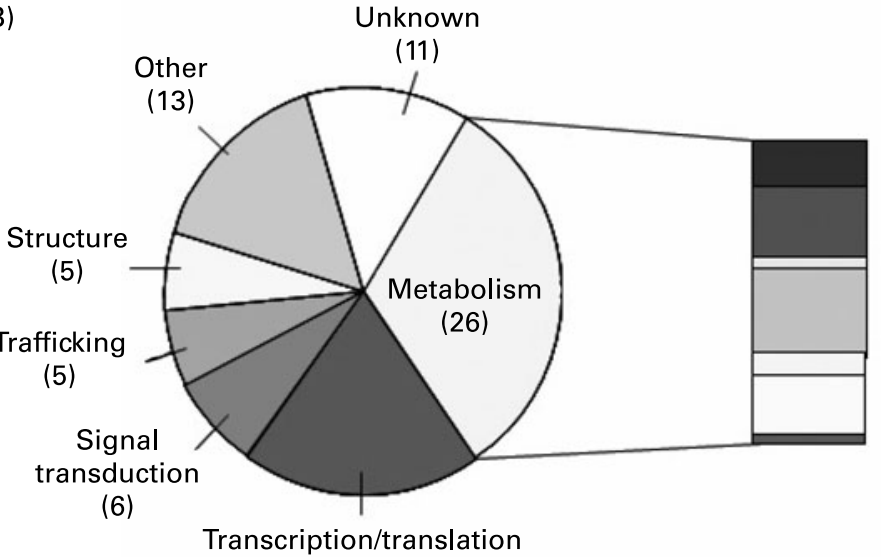

Amino acid (4)

Protein (6)

Carbohydrate (1)

Lipid (7)

Antioxidant (2)

Energy (5)

(16)

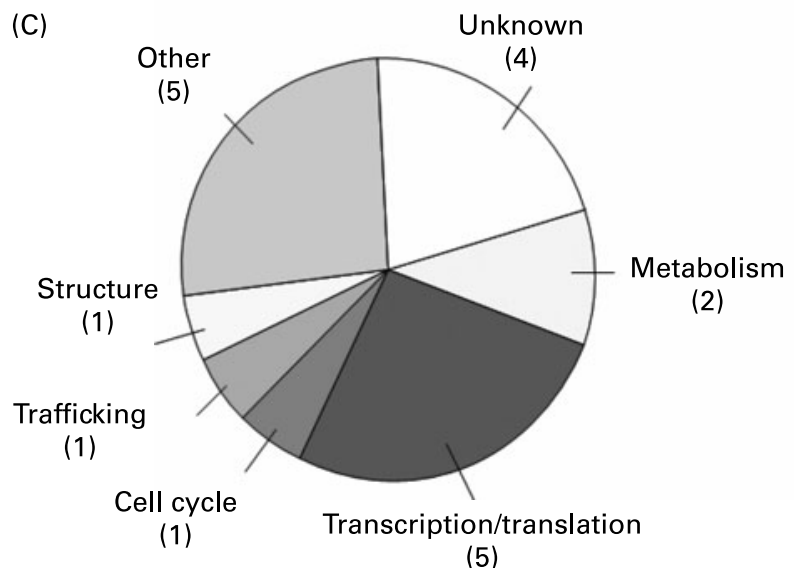

(5)

Fig. 2. Biological functions of the genes differentially expressed according to ANOVA $(P<0.01)$ (A) between the two dietary treatments (high-energy $v$. low-energy) and (B) between the two genetic lines (fat muscle line $v$. lean muscle line) of rainbow trout (Oncorhynchus mykiss). (C) Genes involved in a significant line-diet interaction effect. 
Table 3. Muscle transcripts exhibiting differential expression between the two dietary treatments (high-energy (HE) $v$. low-energy (LE)) in both lines of rainbow trout (Oncorhynchus mykiss), as identified by ANOVA analysis $(P<0.01)$

\begin{tabular}{|c|c|c|c|}
\hline \multirow{2}{*}{ Biological function and clone name } & & \multicolumn{2}{|c|}{ HE:LE ratio } \\
\hline & & L line & $\mathrm{F}$ line \\
\hline \multicolumn{4}{|c|}{ Metabolism (31\%) } \\
\hline \multicolumn{4}{|c|}{ Lipid metabolism (8.9\%) } \\
\hline BX077158 & Very low-density lipoprotein receptor precursor (VLDL-R) & 1.4 & 1.4 \\
\hline BX300637 & Fatty acid translocase/antigen cd36 (FAT/CD36) & 1.4 & 1.4 \\
\hline BX867423 & Peroxisomal 3,2-trans-enoyl-CoA isomerase & -1.5 & -1.5 \\
\hline \multicolumn{4}{|c|}{ Amino-acid derivative metabolism (2.9\%) } \\
\hline CA354115 & L-Serine dehydratase (SDS) & -1.5 & -1.2 \\
\hline \multicolumn{4}{|c|}{ Protein-folding/synthesis/breakdown (17\%) } \\
\hline BX861348 & Ubiquitin carboxyl-terminal hydrolase 2 & -1.4 & $-1 \cdot 1$ \\
\hline CA348824 & Ubiquitin carboxyl-terminal hydrolase isozyme L1 & $-1 \cdot 2$ & -1.5 \\
\hline СА343951 & $26 \mathrm{~S}$ proteasome non-ATPase regulatory subunit 7 & -1.6 & -1.3 \\
\hline CA384189 & Putative serine protease F56F10.1 precursor & 1.5 & 1.3 \\
\hline CA365863 & ATP-dependent Clp protease proteolytic subunit, mitochondrial precursor & $1 \cdot 7$ & $1 \cdot 2$ \\
\hline BX872771 & Augmenter of liver regeneration & -1.5 & $-1 \cdot 3$ \\
\hline \multicolumn{4}{|c|}{ Xenobiotic and oxidant (2.9\%) } \\
\hline CA373646 & Lipoic acid synthetase & 1.3 & 1.8 \\
\hline \multicolumn{4}{|c|}{ Regulation of transcription/translation } \\
\hline BX303258 & DNA-directed RNA polymerase III largest subunit & $1 \cdot 2$ & 1.5 \\
\hline CA353007 & Translation initiation factor elF-2B subunit $\beta$ & $1 \cdot 1$ & 1.3 \\
\hline BX298782 & Polycomb group RING finger protein 4 & $1 \cdot 2$ & 1.3 \\
\hline CA365421 & Homeobox protein Hox-A2b & -3.6 & -1.6 \\
\hline BX087067 & Methyl-CpG-binding domain protein 3 & -1.6 & $-1 \cdot 2$ \\
\hline CA343779 & CCAAT/enhancer-binding protein $\delta$ (C/EBP $\delta)$ & $-1 \cdot 8$ & $-1 \cdot 2$ \\
\hline СА349800 & Nuclear pore complex protein Nup93 & -1.4 & -1.3 \\
\hline CA347895 & Transcription factor 21 & -1.4 & $-2 \cdot 3$ \\
\hline \multicolumn{4}{|c|}{ Signal transduction } \\
\hline СА346554 & Mitogen-activated protein-binding protein-interacting protein & 1.3 & 1.2 \\
\hline CA385556 & Ras GTPase-activating protein 2 & $1 \cdot 2$ & 1.5 \\
\hline CA355642 & Regulator of G-protein signalling 18 & -1.4 & -1.4 \\
\hline CA344992 & Frizzled-7 precursor (Fz-7) & -1.1 & -1.6 \\
\hline CА344649 & Ras-related $\mathrm{C} 3$ botulinum toxin substrate 2 precursor & -1.3 & $-1 \cdot 2$ \\
\hline CA385863 & Brother of $\mathrm{CDO}$ precursor (Protein $\mathrm{BOC}$ ) & $-1 \cdot 2$ & -1.4 \\
\hline СА364621 & RAC- $\alpha$ serine/threonine-protein kinase & -1.4 & $-1 \cdot 3$ \\
\hline \multicolumn{4}{|l|}{ Miscellaneous } \\
\hline BX888224 & Calponin homology domain-containing protein 1 & 1.4 & 1.4 \\
\hline CA355259 & Annexin A13 & 1.8 & 1.3 \\
\hline BX867827 & Acid sphingomyelinase-like phosphodiesterase $3 a$ precursor & 1.4 & 1.2 \\
\hline CA367722 & Hsp90 co-chaperone Cdc37 & $1 \cdot 2$ & 1.3 \\
\hline CA342763 & YTH domain family protein 2 & $1 \cdot 2$ & 1.5 \\
\hline \multicolumn{4}{|l|}{ Unknown } \\
\hline BX084012 & Protein C14orf4 homologue & 1.2 & 1.4 \\
\hline CA358365 & Hypothetical protein ywlC & $1 \cdot 8$ & $1 \cdot 1$ \\
\hline CA354428 & Unknown & 1.3 & 1.7 \\
\hline
\end{tabular}

$L$, lean muscle line; $F$, fat muscle line.

Real time RT-PCR results also confirmed the higher transcript levels observed in the $\mathrm{F}$ line for ADT $\left(P<10^{-4}\right)$ (Fig. 3). In agreement with the microarray data, no significant difference in ADT transcript level was observed between the two dietary groups. In contrast, the specific primer pairs we designed for PPAR $\alpha$ and CEL did not allow sufficient amplification of these transcripts for effective detection, indicating a very low level of expression of these transcripts in the muscle. This disparity may have resulted from a false-discovery error or from cross-hybridisation of transcripts to regions of similarity of the PPAR $\alpha$ and CEL cDNA spotted onto the arrays.

\section{Discussion}

Muscle fat content in farm animals has effects both on muscle physiology and on meat quality. However, relatively little is known about the molecular mechanisms that determine muscle fat deposition. Because the white muscle of rainbow trout as other salmonids generally has high but variable fat content $^{(4,8,9)}$ and is capable of mobilising these fat reserves (as for instance during migration), these species can be considered as particularly suitable for the study of mechanisms involved in muscle fat deposition and utilisation. The present study is the first ever attempt to analyse the molecular mechanisms involved in lipid deposition in the white muscle of rainbow trout. Muscle transcriptome analysis was applied as a high-throughput technology for identification of unappreciated molecular actors that responded to the dietary treatments and the selection procedure. We then performed quantitative RT-PCR to measure mRNA levels of the genes that were identified as differently expressed from analyses of microarray data by two-way ANOVA $(P<0.01)$, and that 
Table 4. Muscle transcripts exhibiting differential expression between the two lines (fat muscle line $(F) v$. lean muscle line $(L)$ ) of rainbow trout (Oncorhynchus mykiss) in both dietary groups, as identified by ANOVA analysis $(P<0.01)$

\begin{tabular}{|c|c|c|c|}
\hline \multirow[b]{2}{*}{ Biological function and clone name } & & \multicolumn{2}{|c|}{$F: L$ ratio } \\
\hline & & LE diet & HE diet \\
\hline \multicolumn{4}{|l|}{ Metabolism (32\%) } \\
\hline \multicolumn{4}{|l|}{ Lipid metabolism } \\
\hline BX311641 & Cardiolipin synthetase-1·1 & $1 \cdot 1$ & 2.5 \\
\hline BX073438 & Carboxyl ester lipase & 1.3 & $2 \cdot 2$ \\
\hline CA352463 & 2-Hydroxyphytanoyl-CoA lyase & $1 \cdot 2$ & 1.2 \\
\hline СА347411 & Proactivator polypeptide precursor & $1 \cdot 2$ & 1.3 \\
\hline BX302544 & Protein ARV1 & 1.3 & 1.3 \\
\hline BX300814 & PPAR $\alpha$ & $-1 \cdot 2$ & $-2 \cdot 0$ \\
\hline CA366030 & PGE synthase 2 & -1.5 & $-1 \cdot 3$ \\
\hline \multicolumn{4}{|c|}{ Generation of precursor metabolites and energy } \\
\hline СА345607 & Isocitrate dehydrogenase (NADP) 2 & 1.3 & 1.5 \\
\hline BX865617 & ADP/ATP translocase & 1.2 & 1.4 \\
\hline CA352391 & Cytochrome c oxidase subunit 3 & 1.8 & 1.4 \\
\hline CA379757 & Decaprenyl-diphosphate synthase subunit 2 & 1.3 & 1.3 \\
\hline САЗ65064 & Molybdenum cofactor biosynthesis protein $1 \mathrm{~B}$ & $1 \cdot 2$ & $1 \cdot 2$ \\
\hline \multicolumn{4}{|l|}{ Amino-acid derivative metabolism } \\
\hline CA357276 & 3-Mercaptopyruvate sulfurtransferase & $1 \cdot 2$ & 1.3 \\
\hline СА345917 & Guanidinoacetate N-methyltransferase & 1.3 & 1.7 \\
\hline CА345342 & Serine-pyruvate aminotransferase, mitochondrial precursor & $-1 \cdot 3$ & $-1 \cdot 6$ \\
\hline САЗ34534 & Kynureninase & $-1 \cdot 7$ & $-1 \cdot 7$ \\
\hline \multicolumn{4}{|c|}{ Protein-folding/synthesis/breakdown (17\%) } \\
\hline BX297091 & Ubiquitin carboxyl-terminal hydrolase 28 & $1 \cdot 2$ & 1.5 \\
\hline СА346736 & Acetohydroxy-acid synthase & 1.3 & 1.8 \\
\hline CA341937 & T-complex protein 1 subunit theta & $1 \cdot 1$ & 1.6 \\
\hline СА342154 & Peptidyl-prolyl cis-trans isomerase B precursor & $1 \cdot 1$ & 1.4 \\
\hline СА346477 & $\alpha-2,8$-Sialyltransferase $8 \mathrm{~F}$ & 1.4 & 1.3 \\
\hline BX303582 & F-box only protein 6 & 1.2 & 1.5 \\
\hline \multicolumn{4}{|l|}{ Xenobiotic and oxidant metabolism } \\
\hline BX074191 & ATP-binding cassette sub-family B member 7 & -1.5 & $-1 \cdot 1$ \\
\hline CA348235 & Cytochrome P450 2K1 & $-1 \cdot 3$ & $-1 \cdot 2$ \\
\hline \multicolumn{4}{|l|}{ Carbohydrate metabolism } \\
\hline BX084018 & Trehalase precursor (EC 3.2.1.28) & $-1 \cdot 1$ & -1.5 \\
\hline \multicolumn{4}{|l|}{ Cu metabolism } \\
\hline BX305643 & Copper-transporting ATPase 1 & $1 \cdot 2$ & 1.7 \\
\hline \multicolumn{4}{|l|}{ Regulation of transcription/translation } \\
\hline CA363479 & Cysteinyl-tRNA synthetase, cytoplasmic (EC 6.1.1.16) & 1.9 & 1.3 \\
\hline CA358296 & Mitochondrial 39S ribosomal protein L39 & $1 \cdot 2$ & 1.4 \\
\hline CA344147 & Eukaryotic translation initiation factor 3 subunit 2 & 1.5 & $1 \cdot 1$ \\
\hline СА365421 & Homeobox protein Hox-A2b & 1.6 & $3 \cdot 8$ \\
\hline CA377690 & Nuclear transcription factor $Y$ subunit $\beta$ & 1.3 & 1.4 \\
\hline САЗ378568 & Pre-mRNA-splicing factor syf2 & 1.3 & 1.4 \\
\hline BX314809 & DNA-directed RNA polymerase III subunit $\mathrm{F}$ (EC 2.7.7.6) & $1 \cdot 1$ & $2 \cdot 2$ \\
\hline СА341803 & Eukaryotic translation initiation factor 3 subunit 4 & 1.4 & 1.4 \\
\hline СА343545 & $40 S$ ribosomal protein $\mathrm{S} 13$ & 1.4 & $1 \cdot 3$ \\
\hline BX875597 & $40 S$ ribosomal protein $\mathrm{S} 17$ & 1.3 & 1.4 \\
\hline СА343637 & $60 S$ acidic ribosomal protein $\mathrm{P} 2$ & 1.3 & 1.4 \\
\hline СА345781 & $60 S$ ribosomal protein L24 & 1.2 & 1.5 \\
\hline CА342765 & Arginyl-tRNA synthetase, cytoplasmic (EC 6.1.1.19) & -1.4 & -1.4 \\
\hline CA351058 & RNA polymerase II elongation factor ELL & $-1 \cdot 3$ & $-1 \cdot 2$ \\
\hline CA362326 & Zn finger protein-like 1 & -1.3 & -1.6 \\
\hline BX297360 & Homeobox protein GBX-1 & $-1 \cdot 2$ & $-1 \cdot 6$ \\
\hline \multicolumn{4}{|l|}{ Signal transduction } \\
\hline САЗ38399 & TNF receptor-associated factor 2 & 1.3 & 1.3 \\
\hline CA364863 & Serine/threonine-protein kinase 19 & 1.4 & 1.2 \\
\hline CA357556 & Guanine nucleotide-binding protein $\gamma-3$ subunit & 1.4 & 1.3 \\
\hline BX866310 & Mitogen-activated protein kinase kinase kinase kinase 2 & $-1 \cdot 2$ & -1.4 \\
\hline CА341936 & Serine/threonine-protein kinase D3 & -1.3 & -1.6 \\
\hline BX320696 & Casein kinase II subunit $\beta$ & $-1 \cdot 2$ & $-1 \cdot 3$ \\
\hline \multicolumn{4}{|l|}{ Cellular trafficking } \\
\hline СА346849 & Unc-13 homologue C & 1.5 & 1.2 \\
\hline СА376723 & Gelsolin precursor & 1.4 & 1.2 \\
\hline CA351559 & Latrophilin-2 precursor & $1 \cdot 8$ & $1 \cdot 2$ \\
\hline СА360465 & B-cell receptor-associated protein 29 & 1.5 & 1.7 \\
\hline CA358906 & $\gamma$-Aminobutyric acid receptor-associated protein & 1.5 & 1.5 \\
\hline Structure & & & \\
\hline САЗ363233 & Spondin-1 precursor & 1.5 & $1 \cdot 2$ \\
\hline СА363745 & Tubulin-specific chaperone A & 1.2 & 1.3 \\
\hline
\end{tabular}


Table 4. Continued

\begin{tabular}{|c|c|c|c|}
\hline \multirow[b]{2}{*}{ Biological function and clone name } & & \multicolumn{2}{|c|}{$F: L$ ratio } \\
\hline & & LE diet & HE diet \\
\hline BX860799 & Bullous pemphigoid antigen 1 (hemidesmosomal protein) & $1 \cdot 1$ & 1.9 \\
\hline CA345128 & Cellular myosin heavy chain, type $A$ & 1.5 & $2 \cdot 1$ \\
\hline \multicolumn{4}{|l|}{ Miscellaneous } \\
\hline CA387939 & Chromosome region maintenance 1 protein homologue & 1.6 & 1.5 \\
\hline CA358005 & Hb subunit $\alpha$ & 1.4 & 1.9 \\
\hline CA346506 & Osteopetrosis-associated transmembrane protein 1 precursor & 1.3 & 1.3 \\
\hline CA379313 & DNA repair protein RAD51 homologue A & 1.5 & 1.3 \\
\hline CA342488 & Polypyrimidine tract-binding protein 2 & 1.3 & 1.6 \\
\hline BX080425 & Zygotic DNA replication licensing factor $\mathrm{mcm} 6$ & 1.4 & 1.5 \\
\hline CA361755 & Cell division cycle 5 -related protein & & \\
\hline BX869597 & Uromodulin-like 1 precursor & -1.4 & $-1 \cdot 2$ \\
\hline CA352407 & $\mathrm{H}-2$ class II histocompatibility antigen, $\alpha$ chain precursor & -1.8 & $-1 \cdot 2$ \\
\hline BX877741 & Retrovirus-related Pol polyprotein from transposon 17.6 & $-1 \cdot 2$ & -1.5 \\
\hline САЗ43383 & Nocturnin & -1.5 & -1.4 \\
\hline BX301281 & TBC1 domain family member 8 & -1.2 & -1.7 \\
\hline \multicolumn{4}{|l|}{ Unknown } \\
\hline CА345936 & Hypothetical $29.3 \mathrm{kDa}$ protein & 1.3 & $1 \cdot 1$ \\
\hline CA350374 & Ankyrin repeat domain-containing protein 39 & $1 \cdot 3$ & 1.3 \\
\hline CA376426 & Adrenal medulla $50 \mathrm{kDa}$ protein & 1.4 & $1 \cdot 2$ \\
\hline CA356186 & AFG3-like protein 2 & 1.3 & 1.3 \\
\hline BX076268 & Neutrophil cytosol factor 2 & 1.4 & 1.8 \\
\hline CA354044 & Sulfatase-modifying factor 2 precursor & $1 \cdot 3$ & 1.2 \\
\hline BX877019 & WD repeat protein 35 & -1.6 & -1.6 \\
\hline BX074012 & THAP domain-containing protein 11 & $-1 \cdot 3$ & -1.3 \\
\hline BX876294 & Protein KIAA0415 & $-1 \cdot 3$ & $-1 \cdot 3$ \\
\hline
\end{tabular}

LE, low-energy; HE, high-energy.

were thought to be involved in metabolic pathways related to the observed phenotypes.

\section{Long-term effects of a high-energy and high-lipid diet on} muscle gene expression profile

The microarray data showed little diet-induced change in the muscle transcriptome, although muscle fat content in fish fed the HE diet was 1.5-fold greater than that in fish fed the LE diet. This is, however, consistent with the results derived from a previous study conducted on the same animals, in which we analysed several key enzymes involved in lipid metabolism, glycolysis and energy production at gene expression and activity levels ${ }^{(13)}$. An interesting finding here is that the level of two transcripts encoding proteins involved in mediating blood-derived lipid delivery to the cell, i.e. FAT/ CD36 and the VLDL receptor, was significantly increased in muscle following long-term feeding of the HE diet. SDH, a key enzyme of amino acid catabolism that transforms serine into pyruvate, and transcripts involved in the regulation of the proteasome-dependent proteolysis process were underexpressed in fish fed the HE diet, compared with those fed the LE diet. Fish swiftly use proteins as oxidative substrates to meet energy requirements ${ }^{(24,25)}$. It has been fully established in fish that increasing non-protein energy-yielding nutrients such as lipids generally leads to a protein-sparing effect, probably by redirecting dietary protein and amino acids from energy production toward tissue deposition ${ }^{(26,27)}$. White muscle protein accretion which determines somatic growth rate ${ }^{(28)}$ results from the balance between protein synthesis and protein degradation rates. The present results suggest a decrease in muscle protein breakdown and subsequent amino acid catabolism associated with increased availability of dietary fat for energy purposes. This is consistent with the enhanced growth observed in fish fed the HE diet and especially the higher protein efficiency ratio in the same group of fish ${ }^{(13)}$.

Taken together, these results suggest that increasing the energy content of the diet induced minor changes in white muscle metabolism of rainbow trout, and that transporterfacilitated uptake of circulating lipids by muscle is likely to be the major mechanism responsible for the higher muscle fat content in salmonids fed HE diets. This is in agreement with the close correlation generally observed between dietary and muscle fatty acid composition in fish ${ }^{(29)}$ as in most single-stomached animals ${ }^{(30-32)}$.

\section{Muscle transcripts affected by the selection process}

Compared with L line muscle, F line muscle exhibited higher levels of transcripts encoding ADT and cytochrome c oxidase subunit 3. Since ADT and cytochrome c oxidase subunit 3 are both rate-controlling enzymes of mitochondrial oxidative phosphorylation, we can hypothesise that higher ATP production occurred in $\mathrm{F}$ line muscle than in $\mathrm{L}$ line muscle. In a previous study using the same animals ${ }^{(13)}$, we evidenced higher activity and gene expression of both hexokinase-I and pyruvate kinase in muscle of the $\mathrm{F}$ line compared with the L line, suggesting greater glycolytic activity in the muscle for the former. We did not find any significant effect on key enzymes of peroxisomal and mitochondrial fatty acid oxidation in muscle induced by selection, except for one 
Table 5. Muscle transcripts involved in a significant line-diet interaction identified by ANOVA analysis $(P<0.01)$

(Mean values and standard deviations)

\begin{tabular}{|c|c|c|c|c|c|c|c|c|c|}
\hline \multirow[b]{3}{*}{ Biological function and clone name } & & \multicolumn{8}{|c|}{ Diet } \\
\hline & & \multicolumn{2}{|c|}{ L-LE } & \multicolumn{2}{|c|}{ L-HE } & \multicolumn{2}{|c|}{ F-LE } & \multicolumn{2}{|c|}{$\mathrm{F}-\mathrm{HE}$} \\
\hline & & Mean & SD & Mean & SD & Mean & SD & Mean & SD \\
\hline \multicolumn{10}{|l|}{ Metabolism } \\
\hline BX856197 & P2X purinoceptor 3 & $0.014^{\mathrm{a}}$ & 0.013 & $-0.152^{b}$ & 0.036 & $0.008^{\mathrm{a}}$ & 0.028 & $0.043^{\mathrm{a}}$ & 0.028 \\
\hline CA342307 & Deoxyuridine dUTP pyrophosphatase & $-0 \cdot 107^{b}$ & 0.016 & $0.081^{\mathrm{a}}$ & 0.035 & $0.012^{\mathrm{a}, \mathrm{b}}$ & 0.35 & $-0.027^{a, b}$ & 0.050 \\
\hline \multicolumn{10}{|c|}{ Regulation of transcription/translation } \\
\hline САЗ32029 & Zn-binding protein $A 33$ & $0.077^{\mathrm{a}, \mathrm{b}}$ & 0.055 & $0.031^{\mathrm{a}, \mathrm{b}}$ & 0.021 & $-0.127^{a}$ & 0.042 & $0 \cdot 127^{b}$ & 0.055 \\
\hline BX872208 & MORC family $\mathrm{CW}$-type $\mathrm{Zn}$ finger protein $2 \mathrm{~A}$ & $-0.099^{b}$ & 0.019 & $0.153^{\mathrm{a}}$ & 0.031 & $0.020^{\mathrm{a}, \mathrm{b}}$ & 0.031 & $-0.008^{b}$ & 0.051 \\
\hline BX314809 & DNA-directed RNA polymerase III subunit $F$ & $0.005^{a, b}$ & 0.039 & $-0.136^{b}$ & 0.063 & $-0.003^{a, b}$ & 0.042 & $0.207^{\mathrm{a}}$ & 0.078 \\
\hline CA387701 & Poly (ADP-ribose) polymerase 14 & $-0.032^{\mathrm{a}, \mathrm{b}}$ & 0.022 & $0 \cdot 217^{\mathrm{a}}$ & 0.092 & $0.005^{\mathrm{a}, \mathrm{b}}$ & 0.023 & $-0.090^{b}$ & 0.023 \\
\hline CA351413 & Histone $\mathrm{H} 1-\beta$, late embryonic & $-0.075^{b}$ & 0.035 & $0.157^{\mathrm{a}}$ & 0.054 & $0.049^{a, b}$ & 0.045 & $-0.016^{a, b}$ & 0.032 \\
\hline \multicolumn{10}{|l|}{ Vesicle-mediated transport } \\
\hline CA370385 & Kinesin-like protein KIF1B & $-0.080^{b}$ & 0.045 & $0.164^{\mathrm{a}}$ & 0.056 & $0.033^{a, b}$ & 0.019 & $-0.068^{b}$ & 0.040 \\
\hline \multicolumn{10}{|l|}{ Structure } \\
\hline CA343182 & $\gamma$-Adducin & $-0.005^{a, b}$ & 0.040 & $0 \cdot 165^{a}$ & 0.060 & $0.092^{\mathrm{a}, \mathrm{b}}$ & 0.038 & $-0 \cdot 101^{b}$ & 0.042 \\
\hline CA361563 & NGF-inducible anti-proliferative protein $\mathrm{PC} 3$ & $-0.013^{a, b}$ & 0.035 & $0 \cdot 104^{\mathrm{a}}$ & 0.039 & $0.014^{\mathrm{a}, \mathrm{b}}$ & 0.014 & $-0.127^{b}$ & 0.062 \\
\hline \multicolumn{10}{|l|}{ Miscellaneous } \\
\hline CB486388 & $\begin{array}{l}\text { Phosphorylase b kinase } \gamma \text { catalytic chain, } \\
\text { skeletal muscle isoform }\end{array}$ & $0 \cdot 150^{\mathrm{a}}$ & 0.045 & $-0.116^{b}$ & 0.041 & $-0.072^{b}$ & 0.027 & $0.058^{\mathrm{a}, \mathrm{b}}$ & 0.066 \\
\hline BX084629 & $\gamma$-Aminobutyric-acid receptor subunit $\alpha-1$ & $-0.043^{b}$ & 0.042 & $0.173^{\mathrm{a}}$ & 0.025 & $-0.015^{b}$ & 0.030 & $-0.006^{b}$ & 0.039 \\
\hline BX082422 & Globoside $\alpha-1,3-\mathrm{N}$-acetylgalactosaminyltransferase 1 & $-0.116^{b}$ & 0.034 & $0 \cdot 171^{\mathrm{a}}$ & 0.046 & $-0.030^{b}$ & 0.034 & $0.020^{\mathrm{a}, \mathrm{b}}$ & 0.041 \\
\hline BX082670 & Protein odd-skipped-related 1 & $-0.054^{b}$ & 0.024 & $0.026^{a, b}$ & 0.042 & $0.130^{\mathrm{a}}$ & 0.010 & $-0.017^{\mathrm{a}, \mathrm{b}}$ & 0.036 \\
\hline CА346811 & Retrotransposable element Tf2 $155 \mathrm{kDa}$ protein type 1 & $0.014^{\mathrm{a}, \mathrm{b}}$ & 0.032 & $0.150^{\mathrm{a}}$ & 0.031 & $0.011^{a, b}$ & 0.035 & $-0.097^{b}$ & 0.028 \\
\hline \multicolumn{10}{|c|}{ 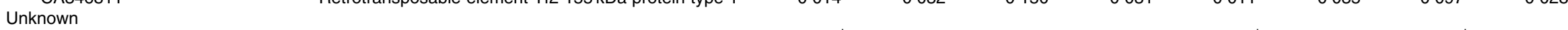 } \\
\hline BX882876 & Scrapie-responsive protein 1 precursor & $-0.078^{b}$ & 0.024 & $0.208^{\mathrm{a}}$ & 0.055 & $0.018^{b}$ & 0.031 & $0.002^{b}$ & 0.027 \\
\hline BX860222 & Hypothetical oxidoreductase yulF & $-0.010^{a, b}$ & 0.035 & $-0.163^{b}$ & 0.056 & $0.015^{a, b}$ & 0.052 & $0.231^{\mathrm{a}}$ & 0.069 \\
\hline BX869292 & Unknown & $0.036^{\mathrm{a}}$ & 0.017 & $-0.156^{b}$ & 0.025 & $-0.015^{a}$ & 0.028 & $-0.012^{\mathrm{a}}$ & 0.025 \\
\hline BX297572 & Unknown & $-0.001^{a, b}$ & 0.032 & $-0.071^{b}$ & 0.027 & $-0.042^{b}$ & 0.035 & $0 \cdot 125^{\mathrm{a}}$ & 0.022 \\
\hline
\end{tabular}

$L$, lean muscle line; LE, low-energy; HE, high-energy; $F$, fat muscle line.

${ }^{a, b}$ Mean values with unlike superscript letters were significantly different $(P<0.01)$. 
(A)

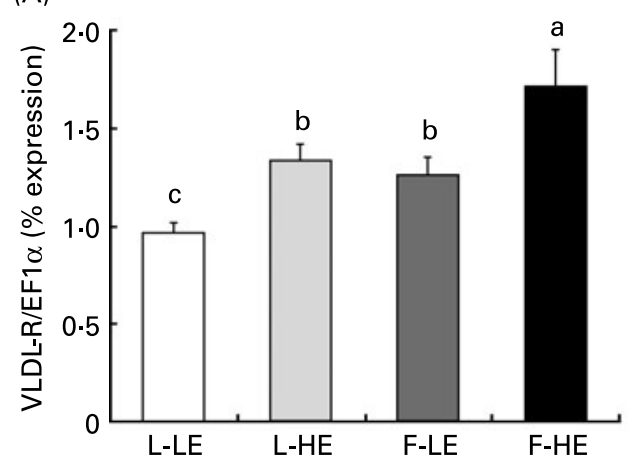

(C)

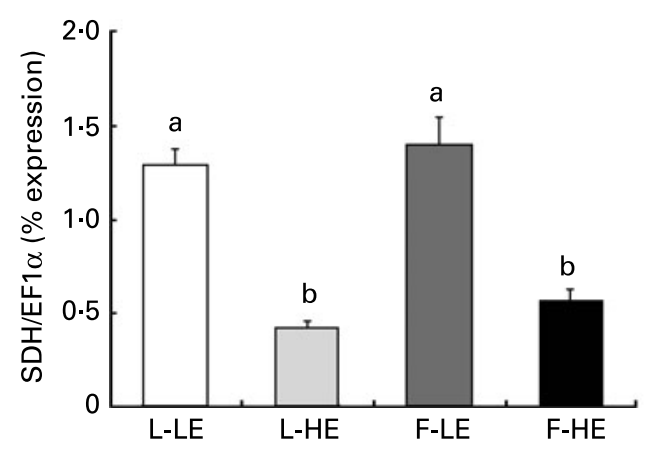

(B)

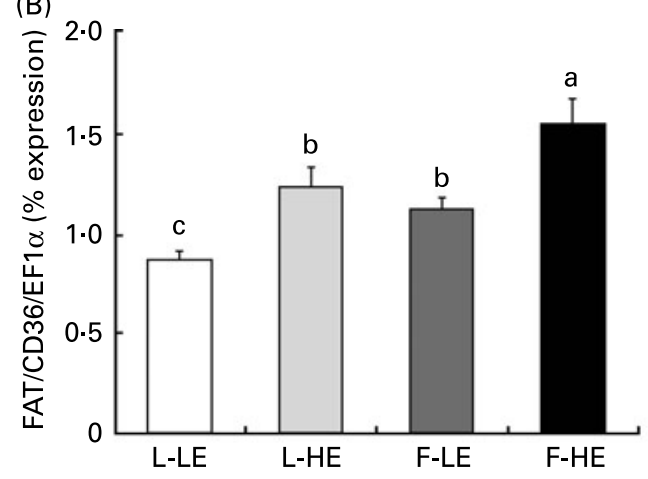

(D)

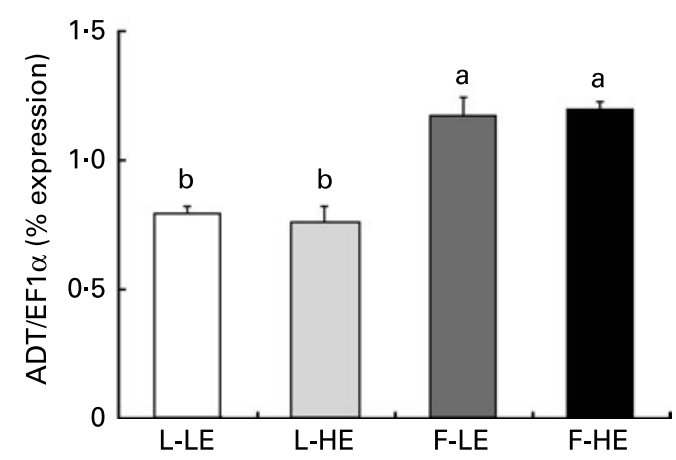

Fig. 3. Gene expression of selected genes measured by real-time quantitative RT-PCR (controls of the microarray data) in the white muscle of rainbow trout (Oncorhynchus mykiss) from the lean muscle line (L) and fat muscle line (F) fed the low-energy (LE) and high-energy (HE) diets for 6 months. Data are means of eight samples performed in triplicate, with standard errors represented by vertical bars. Expression values were normalised with elongation factor $1 \alpha(E F 1 \alpha)$ expressed transcripts. (A) Gene expression measurement of VLDL receptor (VLDL-R). HE $>$ LE $\left(P=10^{-4}\right)$; F $>$ L $\left(P<5 \times 10^{-3}\right)$ (two-factor ANOVA). (B) Gene expression measurement of fatty acid translocase/CD36 (FAT/CD36). HE $>$ LE $\left(P=10^{-4}\right)$; F $>$ L $\left(P<10^{-2}\right)$ (two-factor ANOVA). (C) Gene expression measurement of L-serine dehydratase $(\mathrm{SDH})$. HE $>$ LE $\left(P<10^{-4}\right)$ (two-factor ANOVA). (D) Gene expression measurement of ATP/ADP translocase (ADT). $\mathrm{F}>\mathrm{L}$ $\left(P<10^{-4}\right)$ (two-factor ANOVA). ${ }^{\text {a,b,c }}$ Mean values with unlike letters were significantly different $(P<0.05 ;$ ANOVA).

isoform of carnitine palmitoyl-transferase I (CPTIb), the mRNA level of which was higher in the $\mathrm{F}$ line than in the $\mathrm{L}$ line. The white muscle of rainbow trout is mainly composed of fast glycolytic fibres, which utilise fatty acids as fuel rather poorly except during recovery from exhausting swim$\operatorname{ming}^{(2)}$. Hence, the enhanced mitochondrial oxidative phosphorylation activity in the $\mathrm{F}$ line suggested in the present study can be related to a greater reliance of the $F$ line muscle on glycolysis for energy production as evidenced by the higher activity and gene expression of hexokinase I and pyruvate kinase observed in the muscle of the $\mathrm{F}$ line ${ }^{(13)}$.

A high level of expression of a transcript exhibiting high sequence similarity with CEL was detected in muscle of the $\mathrm{F}$ line. CEL, also known as bile-salt activated lipase, is a non-specific lipolytic enzyme capable of hydrolysing cholesteryl esters, acylglycerols and phospholipids ${ }^{(33)}$. Although this enzyme is synthesised primarily in the pancreatic cells and lactating mammary glands of mammals, CEL expression was also detected in the muscle of two pig breeds (Duroc and Taoyuan) through a transcriptome analysis $^{(34)}$. CEL transcript level was higher in the muscle of the Chinese breed, which displayed a greater level of fatness than the Western breed. This leads us to believe CEL to be a potential genetic marker for muscle fat content. However, no further amplification of CEL could be obtained using RT-PCR performed with probes specifically designed according to the sequence that was spotted on the array in the present study. The same was observed for the PPAR $\alpha$ transcript assessed in the present study when another PPAR $\alpha$-specific primer pair allowed us to detect an expression in the previous study with the same samples ${ }^{(13)}$. One possible reason for these discrepancies between the results from microarray and from RT-PCR may be that other transcripts with high sequence similarity (i.e. other isoforms) may be functionally expressed in white muscle and that the primers used in the present study were too specific to allow their amplification and effective detection. This is a major pitfall to be taken into account when working with rainbow trout, due to the many potential paralogues for a still unappreciated number of genes arising from the recent salmonid genome duplication ${ }^{(35)}$.

The most striking result was undoubtedly provided by the real-time RT-PCR measurement of FAT/CD36 and VLDL receptor gene expression, since it revealed that, in addition to being significantly enhanced by the high-fat diet, muscle VLDL receptor/vitellogenin receptor and FAT/CD36 transcript levels were also increased in trout selected for higher muscle fat content. Despite the fact that the range of changes was limited, the transcript level paralleled the muscle fat content of fish, suggesting that long-term moderate changes in expression of genes related to lipid uptake might significantly affect muscle fat content. 
VLDL receptor and fatty acid translocase/CD36 as potential molecular markers for muscle fat deposition in rainbow trout

VLDL receptor is a member of the LDL receptor superfamily. These receptors mediate the internalisation and degradation of lipoproteins. In mammals, VLDL receptor is expressed predominantly on the capillary endothelium ${ }^{(36)}$ of heart, muscle and adipose tissue ${ }^{(37)}$. VLDL receptor binds with high affinity to VLDL, intermediate-density lipoproteins and chylomicrons, but not to $\operatorname{LDL}^{(38,39)}$. Recent studies using VLDL receptordeficient mice have provided compelling evidence that in mammals VLDL receptor has a role in the metabolism of TAG-rich lipoproteins, and is important for postprandial plasma TAG clearance and storage in peripheral tissues ${ }^{(40-42)}$. In contrast, VLDL receptor homologue expression in oviparous animals was thought to be restricted to ovarian tissue where it definitely has a key function in oocyte development by specifically binding to vitellogenin. It was therefore renamed vitellogenin receptor ${ }^{(43)}$. In fact it has been demonstrated that at least two vitellogenin receptor variants co-exist in the chicken, as well as in rainbow trout ${ }^{(44,45)}$, which are distinguished by the presence or absence of an O-linked sugar domain. Whereas the O-linked sugar domain-lacking variant has been found to be highly and exclusively expressed in the ovary, the $\mathrm{O}$-linked sugar-containing variant is expressed as a major form in heart and muscle ${ }^{(44,45)}$. Because studies of vitellogenin receptor/VLDL receptor in egg-laying species such as rainbow trout have so far focused merely on oocyte development, the role played by the somatic form of this receptor and its ligand-binding properties in these species have received little attention. Nevertheless, considering that this receptor is expressed in almost the same tissues as in mammals, it could be argued that this receptor is likely to perform similar functions in oviparous species as in mammals. The present results support the hypothesis, as VLDL receptor was highly expressed in the white muscle of immature rainbow trout, and its mRNA level correlated with the muscle fat level observed across the different experimental groups.

With regard to the physiological role of FAT/CD36, studies in human subjects and mice genetically deficient in FAT/ CD36 have indicated that this transporter determines longchain fatty acid uptake and lipid metabolism in the heart, muscle and adipose tissue ${ }^{(46-48)}$. Expression of FAT/CD36 and VLDL receptor is notably induced during adipocyte differentiation $^{(49)}$. As we worked with the whole white muscle tissue, we cannot assert whether the increase in VLDL receptor and FAT/CD36 mRNA levels observed therein was derived from adipocytes located between the fibres, from the white muscle cells or from both. However, since fat deposition in white muscle in fish mainly occurs as lipid accumulation within adipocytes located in connective tissue surrounding the fibres, it seems reasonable to suggest that this increase in expression of FAT/CD36 and VLDL receptor may have mostly occurred in adipose cells.

Taken together, the present results suggest that enhanced lipid uptake is the major mechanism regulating muscle fat in rainbow trout, irrespective of the means used to tailor muscle fat content. Plasma lipids taken up by muscle are transported in the bloodstream either as TAG-rich lipoproteins (i.e. chylomicrons and VLDL) or as NEFA bound to albumin. TAG-rich lipoproteins are hydrolysed by LPL which generates
NEFA, 2-monoglycerols and remnant lipoprotein particles. NEFA are then transported across the plasma membrane into muscle cells by simple diffusion or by membrane-associated transporters, FAT/CD36 being among the best characterised to date. Remnant lipoprotein particles can be also taken up into cells by receptors such as VLDL receptor. LPL is thus generally considered as the rate-limiting enzyme in the uptake of fatty acids derived from circulating lipoproteins in peripheral tissues ${ }^{(50)}$. In the present study, neither transcript levels nor activity of LPL were modified by the dietary treatment, or by the selection procedure used to modify muscle lipid content ${ }^{(13)}$. This is in line with the lack of correlation observed in muscle between LPL activity and TAG-derived lipid uptake in rats treated with a PPAR $\gamma$ agonist ${ }^{(51)}$, suggesting that the extent of muscle TAG-derived lipid uptake could be independent of changes in LPL per se. When LPL activity is not limiting, the increase of expression of VLDL receptor and FAT/CD36 could be sufficient to mediate an increase in muscle lipid uptake. Some studies have reported a strong relationship between LPL and VLDL receptor in mammals ${ }^{(42,52)}$, suggesting functional cooperation of these proteins in the control of postprandial delivery of lipoprotein-derived fatty acids to tissues. In addition to mediating the internalisation of remnant lipoprotein into the muscle cells, VLDL receptor may also act by facilitating the hydrolysis of TAG-rich lipoproteins by maintaining them in close interaction with LPL.

\section{Conclusions}

The present study provides evidence for changes in lipid uptake mechanisms in response to dietary or genetic determinants. The increase in muscle fat deposition in rainbow trout resulting from feeding a $\mathrm{HE}$ diet seems more likely to be related to enhanced transport and uptake of fatty acids than to changes in intermediary metabolism in the muscle. This is also consistent with the close relationship generally observed between the dietary fatty acid profile and the muscle fatty acid composition. Our data also suggest that VLDL receptor in trout is not only related to vitellogenesis, but may also play a major role in muscle lipid uptake as in mammals. The higher lipid content induced in the muscle by the $\mathrm{HE}$ and high-fat diet and upward selection for muscle fat content was associated with a concomitant increase in transcript levels of FAT/CD36 and VLDL receptor, thus making these genes potential molecular markers for understanding molecular mechanisms underlying intramuscular fat deposition in the white muscle. According to the present results, VLDL receptor and FAT/CD36, and not LPL, could be the rate-limiting enzymes for circulating lipid uptake in rainbow trout white muscle. The relevance of VLDL receptor and FAT/CD36 as molecular markers of muscle fattening needs to be confirmed by further studies with muscle samples from various origins and characterised by different lipid content.

\section{Acknowledgements}

The present study was funded by the French national AGENOP programme (contract no. A02483, Systematic Analysis of Rainbow Trout Genome) and the 6th European Project Cadre of Research and Development (contract no. 016249-2, 
Sustainable Aquafeeds to Maximize the Health Benefits of Farmed Fish for Consumers (AQUAMAX)). C. I. K. was partially supported by a grant from INRA and the Aquitaine region.

We warmly thank Dr S. J. Kaushik for advice and stimulating discussion, M. J. Borthaire for skilled technical assistance and the technical staff at the INRA experimental facilities of Pisciculture Expérimentale Inra des Monts d'Arrée (PEIMA; Sizun, France).

C. I. K. performed sample preparation, microarray hybridisations, integrated the data and drafted the manuscript. E. P.-J. contributed to the microarray hybridisations. E. Q. supervised the production of the two divergent lines. F. M. supervised the whole study together with F. L., conceived of the experimental design, formulated diets, performed quantitative RT-PCR and participated in writing the manuscript. All authors read and approved the final manuscript.

All authors declare no conflict of interest.

\section{References}

1. Jeukendrup AE (2002) Regulation of fat metabolism in skeletal muscle. Ann NY Acad Sci 967, 217-235.

2. Richards J, Heigenhauser G \& Wood C (2002) Lipid oxidation fuels recovery from exhaustive exercise in white muscle of rainbow trout. Am J Physiol Regul Integr Comp Physiol 282, R89-R99.

3. Jaromowska M \& Górski J (1985) Effect of fasting on skeletal muscle triglyceride content. Experientia 41, 357-358.

4. Robb DHF, Kestin SC, Warriss PD, et al. (2002) Muscle lipid content determines the eating quality of smoked and cooked Atlantic salmon (Salmo salar). Aquaculture 205, 345-358.

5. Wood JD, Richardson RI, Nute GR, et al. (2003) Effects of fatty acids on meat quality: a review. Meat Sci 66, 21-32.

6. Pérusse L \& Bouchard C (2000) Gene-diet interactions in obesity. Am J Clin Nutr 72, 1285S-1290S.

7. Weatherup RN, McCracken KJ, Foy R, et al. (1997) The effects of dietary fat content on performance and body composition of farmed rainbow trout (Oncorhynchus mykiss). Aquaculture 151, $173-184$.

8. Einen O \& Skrede G (1998) Quality characteristics in raw and smoked fillets of Atlantic salmon, Salmo salar, fed high-energy diets. Aquac Nutr 4, 99-108.

9. Gélineau A, Corraze G, Boujard T, et al. (2001) Relation between dietary lipid level and voluntary feed intake, growth, nutrient gain, lipid deposition and hepatic lipogenesis in rainbow trout. Reprod Nutr Dev 41, 487-503.

10. Quillet E, Le Guillou S, Aubin J, et al. (2005) Two-way selection for muscle lipid content in pan-size rainbow trout (Oncorhynchus mykiss). Aquaculture 245, 49-61.

11. Henderson RJ \& Sargent J (1981) Lipid biosynthesis in rainbow trout, Salmo gairdnerii, fed diets differing in lipid content. Comp Biochem Physiol C 69, 31-37.

12. Hillgartner FB, Salati LM \& Goodridge AG (1995) Physiological and molecular mechanisms involved in nutritional regulation of fatty acid synthesis. Physiol Rev 75, 47-76.

13. Kolditz C, Borthaire M, Richard N, et al. (2008) Liver and muscle metabolic changes induced by dietary energy content and genetic selection in rainbow trout (Oncorhynchus mykiss). Am J Physiol Regul Integr Comp Physiol 294, R1154-R1164.

14. Govoroun M, Le Gac F \& Guiguen Y (2006) Generation of a large-scale repertoire of expressed sequence tags (ESTs) from normalised rainbow trout cDNA libraries. BMC Genomics 7, 196-203.
15. Nguyen C, Rocha D, Granjeaud S, et al. (1995) Differential gene expression in the murine thymus assayed by quantitative hybridization of arrayed cDNA clones. Genomics 29, 207-216.

16. Cathelin R, Lopez F \& Klopp C (2007) AGScan: a pluggable microarray image quantification software based on the Image J library. Bioinformatics 23, 247-248.

17. National Center for Biotechnology Information (2009) Gene Expression Omnibus home page. http://www.ncbi.nlm.nih. gov/geo/ (accessed July 2009).

18. Saeed AI, Sharov V, White J, et al. (2003) TM4: a free, opensource system for microarray data management and analysis. Biotechniques 34, 374-378.

19. Aegerter S, Baron D, Carpentier C, et al. (2004) The INRA AGENAE program and the Agenae trout EST collections: first results applied to fish physiology research. Comp Biochem Physiol A 137, 135-141.

20. Rexroad CE, Lee Y, Keele JW, et al. (2003) Sequence analysis of a rainbow trout cDNA library and creation of a gene index. Cytogenet Genome Res 102, 347-354.

21. Gish W \& States DJ (1993) Identification of protein coding regions by database similarity search. Nat Genet 3, 266-272.

22. Olsvik P, Lie K, Jordal A, et al. (2005) Evaluation of potential reference genes in real time RT-PCR studies of Atlantic salmon. BMC Mol Biol 17, 6-21.

23. Pfaffl MW (2001) A new mathematical model for relative quantification in real time RT-PCR. Nucleic Acids Res 29, 2002-2007.

24. Van den Thillart G (1986) Energy metabolism of swimming trout ( $S$. gairdneri). Oxidation rates of palmitate, glucose, lactate, alanine, leucine and glutamate. J Comp Physiol B 156, $511-520$

25. Dabrowski K \& Guderley H (2002) Intermediary metabolism. In Fish Nutrition, pp. 309-365 [JE Halver and RW Hardy, editors]. San Diego, CA: Academic Press.

26. Takeuchi T, Watanabe T \& Ogino C (1978) Optimum ratio of dietary energy to protein for rainbow trout. Bull Jpn Soc Sci Fish 44, 729-732.

27. Hillestad M \& Johnsen F (1994) High-energy/low-protein diets for Atlantic salmon: effects on growth, nutrient retention and slaughter quality. Aquaculture 124, 109-116.

28. Weatherly AH \& Gill HS (1989) The role of muscle in determining growth and size in teleost fish. Experientia 45, 875-878.

29. Sargent JR, Henderson RJ \& Tocher DR (1989) The lipids. In Fish Nutrition, pp. 153-218 [JE Halver, editor]. San Diego, CA: Academic Press.

30. Sawosz E, Chachulowa J, Lechowski R, et al. (1999) Influence of dietary lecithin and oil rich in $n-3$ polyunsaturated fatty acids (PUFA) on the fatty acid content of rat muscle and serum. J Anim Feed Sci 8, 485-497.

31. Flachowsky G, Schultz E, Kratz R, et al. (2008) Effects of different dietary fat sources on the fatty acid profile of backfat and intramuscular fat of pigs of various sire breeds. J Anim Feed Sci 17, 363-371.

32. Kouba M, Benatmane F, Blochet JE, et al. (2008) Effect of a linseed diet on lipid oxidation, fatty acid composition of muscle, perirenal fat, and raw and cooked rabbit meat. Meat Sci 80, 829-834.

33. Hui DY (1996) Molecular biology of enzymes involved with cholesterol ester hydrolysis in mammalian tissues. Biochim Biophys Acta 1303, 1-14.

34. Lin CS \& Hsu CW (2005) Differentially transcribed genes in skeletal muscle of Duroc and Taoyuan pigs. J Anim Sci 83, 2075-2086.

35. Bailey GS, Poulter RT \& Stockwell PA (1978) Gene duplication in tetraploid fish: model for gene silencing at unlinked duplicated loci. Proc Natl Acad Sci U S A 75, 5575-5579. 
36. Wyne KL, Pathak RK, Seabra MC, et al. (1996) Expression of the VLDL receptor in endothelial cells. Arterioscler Thromb Vasc Biol 16, 407-415.

37. Sakai J, Hoshino A, Takahashi S, et al. (1994) Structure, chromosome location, and expression of the human very low density lipoprotein receptor gene. J Biol Chem 269, 2173-2182.

38. Takahashi S, Kawarabayasi Y, Nakai T, et al. (1992) Rabbit very low density lipoprotein receptor: a low density lipoprotein receptor-like protein with distinct ligand specificity. Proc Natl Acad Sci U S A 89, 9252-9256.

39. Niemeier A, Gafvels M, Heeren J, et al. (1996) VLDL receptor mediates the uptake of human chylomicron remnants in vitro. J Lipid Res 37, 1733-1742.

40. Tacken PJ, Teusink B, Jong MC, et al. (2000) LDL receptor deficiency unmasks altered VLDL triglyceride metabolism in VLDL receptor transgenic and knock out mice. J Lipid Res 41, 2055-2062.

41. Goudriaan JR, Tacken PJ, Dahlmans VE, et al. (2001) Protection from obesity in mice lacking the VLDL receptor. Arterioscler Thromb Vasc Biol 21, 1488-1493.

42. Yagyu H, Lutz EP, Kako Y, et al. (2002) Very low density lipoprotein (VLDL) receptor-deficient mice have reduced lipoprotein lipase activity. J Biol Chem 277, 10037-10043.

43. Okabayashi K, Shoji H, Nakamura T, et al. (1996) cDNA cloning and expression of the Xenopus laevis vitellogenin receptor. Biochem Biophys Res Commun 224, 406-413.

44. Bujo H, Lindstedt KA, Hermann M, et al. (1995) Chicken oocytes and somatic cells express different splice variants of a multifunctional receptor. J Biol Chem 270, 23546-23551.
45. Prat F, Coward K, Sumpter JP, et al. (1998) Molecular characterization and expression of two ovarian lipoprotein receptors in the rainbow trout, Oncorhynchus mykiss. Biol Reprod 58, $1146-1153$.

46. Watanabe K, Ohta Y \& Toba K (1998) Myocardial CD36 expression and fatty acid accumulation in patients with type I and II CD36 deficiency. Ann Nucl Med 12, 261-266.

47. Fukuchi K, Nozaki S \& Yoshizumi T (1999) Enhanced myocardial glucose use in patients with a deficiency in long-chain fatty acid transport (CD36 deficiency). J Nucl Med 40, 239-243.

48. Coburn CT, Knapp FF, Febbraio M, et al. (2000) Defective uptake and utilization of long chain fatty acids in muscle and adipose tissue of CD36 knockout mice. J Biol Chem 275, $32523-32529$

49. Abumrad NA, El-Maghrabi MR, Amri EZ, et al. (1993) Cloning of rat adipocyte membrane protein implicated in binding or transport of long chain fatty acids that is induced during preadipocyte differentiation: homology with human CD 36. J Biol Chem 268, 17665-17668.

50. Fielding BA \& Frayn KN (1998) Lipoprotein lipase and the disposition of dietary fatty acids. Br J Nutr 80, 495-502.

51. Laplante M, Festuccia WT, Soucy G, et al. (2009) Tissuespecific postprandial clearance is the major determinant of PPAR $\gamma$-induced triglyceride lowering in the rat. Am J Physiol Regul Integr Comp Physiol 296, R57-R66.

52. Roberts CK, Barnard RJ, Liang KH, et al. (2002) Effect of diet on adipose tissue and skeletal muscle VLDL receptor and LPL: implications for obesity and hyperlipidemia. Atherosclerosis 161, 133-141. 